Thuwal, a graduate university created by the king in 2009 , which has a US $\$ 20$-billion endowment. The university is the flagship of Abdullah's efforts both to build a knowledge-based society in a country with little science base and to help distance science and education from the stifling influence and control of conservative clerics.

As we report on page 18, some of these scientists have become caught up in the controversy over Saudi Arabia's human-rights record. An international outcry has been sparked by the Saudi authorities' flogging of the activist Raif Badawi in a public square in January - the first 50 of a sentence of 1,000 lashes, along with 10 years in prison, for posts that he introduced on his website for social and political discussion.

The Badawi case once again highlights the responsibility of researchers and scientific institutions who collaborate with authoritarian and repressive regimes such as Saudi Arabia to denounce human-rights abuses. Eighteen Nobel laureates explicitly raised that point in a letter last month to the president of KAUST, calling for "influential voices in KAUST" to speak out against Badawi's brutal treatment, arguing that no university can be viable in a society lacking basic freedoms.

Some scientists and their institutions, such as the US National Academies of Science, have a long history of speaking out to defend freedoms, and of campaigning on behalf of persecuted academics and activists, although too many others remain silent. Still, there are concerns that such lobbying has lessened in recent years, with several scientific human-rights bodies, including those of the New York Academy of Sciences and the American Association for the Advancement of Science, shifting their focus to scientific diplomacy and softer humanrights issues, such as access to education, clean water, food and health care. Some have argued that working to open up repressive countries is more effective in the long term than publicly embarrassing them over individual cases of abuse.

Others have rightly expressed concern that scientists and their institutions may be increasingly reluctant to speak out to avoid jeopardizing collaborations with countries, including China, that have dismal human-rights records. The many Western universities that have partnerships with KAUST and other Saudi institutions benefit from petrodollars, and the leading researchers who have joined the KAUST faculty benefit from competitive salaries and state-of the-art laboratory

conditions. Western universities have also gained from the influx of hundreds of thousands of fee-paying Saudi students under a generous scholarship scheme established by King Abdullah.

What can scientists there achieve by speaking out? Foreign researchers working at KAUST who were contacted by Nature seem sincerely

"Change cannot be expected to come quickly in Saudi Arabia." a form of diplomacy, for example with Iran, and has similarly opposed proposed scientific boycotts of Israel.

Unfortunately, change cannot be expected to come quickly in Saudi Arabia because of the unique complexity of its society and culture. As Europe's Enlightenment was taking shape in the eighteenth century, pushing back against religious authority and ushering in modern science, the Arabian peninsula was heading in the opposite direction. The Saudi state was born at the time out of an unholy alliance between Ibn Saud, a tribal leader, and Muhammad Ibn Abd al-Wahhab, the leader of Wahhabism, an extreme fundamentalist sect of Sunni Islam. That pact shapes Saudi rule and society to this day, resulting in a symbiotic agreement, with the conservative clerics giving the monarchy its support in return for their power to impose a society based on radical Islam, and an extreme form of sharia law.

But there does not need to be a conflict between defending individual cases - either publicly or by more diplomatic, behindthe-scenes pressure - and broader outreach efforts. We need both. Campaigns for persecuted individuals whose plights otherwise risk going unnoticed can also, as in Badawi's case, send the powerful message that the world is watching. Scientists at KAUST are perhaps not best placed to speak out, being at risk of potential retribution. But Saudi Arabia benefits hugely, not least in terms of its international image, from prominent collaborations with Western research organizations and universities, which have a duty to use that leverage to speak out on abuses, and to call for greater democratic reforms - both publicly and in their private dealings with their Saudi partners.

\section{Road test}

\section{Realizing the benefits of driverless cars will require governments to embrace the technology.}

\section{$\mathrm{T}$} he government funding agency Innovate UK has launched a $£ 10$-million (US\$15-million) project to study how autonomous, self-driving vehicles will fit into daily life in four parts of England: Greenwich, Coventry, Milton Keynes and Bristol.

Good job. That is the right kind of question to ask about driverless cars. As described in a News Feature on page 20, developers such as Google are making rapid progress on the vehicles. From a technical standpoint, the cars could be ready for widespread deployment within a decade. But when and how they will hit the streets depends on how well people accept and trust them.

Consider, for example, the obvious economic question: will people be able to afford them? Thanks to the need for sophisticated equipment, the vehicles are likely to be much more expensive than their conventional counterparts, at least initially. And that means that buyers will need to see correspondingly large benefits.

A frequently cited benefit is safety: advocates insist that the vehicles could all but eliminate accidents. But convincing people that driverless cars can do away with human accidents and not make robot-minded mistakes of their own is likely to take a good number of years and millions of kilometres of accident-free test drives.

And when accidents do happen - as they surely will - public reaction will depend on the specifics of the event, and those are hard to predict. The legal issues may be even tougher. Right now, equipment failures are rare and the responsibility almost always rests with a driver. But with driverless vehicles, the courts and insurance companies will have to figure out how to apportion liability among the vehicle's occupants (who may be dozing off), the car maker, the software developers and even the mapping algorithm.

Another much-touted benefit is fuel efficiency. But that is unlikely to be realized until most cars are equipped with systems that allow them to communicate with one another (called V2V systems) and with traffic signals to minimize stop-and-go traffic.

Of course, some wealthy people will doubtless take the plunge. But the most important early adopters will probably be fleet operators: driverless ride-share systems could function as a new form of mass transit. And if the door-to-door service encourages more people to give up their car, then some of the vast areas devoted to parking could be put to other uses.

Governments are likely to be crucial to the transition - not least because many of the benefits accrue to society as a whole. A good example is being set by the United States, which is considering a mandate that would greatly speed up the transition by requiring V2V radios in every $\checkmark$ NATURE.COM To comment online, click on Editorials at: go.nature.com/xhunqv new US car. Other countries should follow suit. To make such moves fully effective, however, local governments will need to start upgrading roadways with smart signals designed to optimize traffic flow - assuming they can find the money. 